\title{
PREDIKSI EROSI BERBAGAI POLA USAHA TALI DI DESA PALATTA KECAMATAN TAPANGO KABUPATEN POLEWALI MANDAR
}

\author{
Qaizar K \\ Dosen Fakultas Pertanian dan Kehutanan Universitas Sulawesi Barat
}

\begin{abstract}
This study aims to (1) Predicting the actual erosion and erosion determine which allowed the various patterns of farming in the village Palatta Tapango District of Polewali Mandar, (2) Formulate soil and water conservation measures on each pattern farm. This researh was conducted in the village of the District Palatta Tapango Polewali Mandar. Data collected through direct observation of the research object in the field. The method used in predicting the amount of erosion is common soil loss equation (USLE method). The result showed that the amount of erosion that accurs in six patterns of farming is 42.76 tons per hectare per year. Based sixth farming patterns were obtained magnitude of the rate erosion on any bentukpola,namely (1)Gamal, banan, jackfruit, durian, Grass 17.86 tonnes per hectare per year, (2) Brown, of falm, Rambutan, Gamal, Litter 10.08 tons per hectare per year, (3) Sengon, Banana, Mango, Chocholate, Coffe, Bushes 4.70 tonnes per hectare per year, (4) Brown, Pinus, Litter 4.20 tonnes per hectare per year, (5) of palm, Brown, jackfruit, banana,Gamal, Litter 3.61 tonnes per hectare per year, and (6) Langsat, Durian, Brown, grass 2,31 tons per hectare per year. The amount of erosion that occurs in various patterns of faming still exceeds the amount of erosion is allowed. To that end, the necessary efforts to reduce the rate of erosion of soil conservation practices and land uses that provide protection or land cover better.
\end{abstract}

\begin{abstract}
Abstrak
Penelitian ini bertujuan untuk (1) Meprediksi erosi aktual dan menentukan erosi yang diperkenankan pada berbagai pola usaha tani di Desa Palatta Kecamatan Tapango Kabupaten Polewali Mandar, (2) Merumuskan tindakan konservasi tanah dan air pada setiap pola usaha tani. penelitian ini dilaksanakan di Desa Palatta Kecamatan Tapango Kabupaten Polewali Mandar. Pengumpulan data dilakukan melalui pengamatan langsung terhadap objek penelitian di lapangan. Metode yang digunakan dalam memprediksi besarnya erosi adalah persamaan umum kehilangan tanah (metode USLE). Hasil penelitian menunjukkan bahwa besarnya laju erosi yang terjadi pada enam pola usahatani tersebut diperoleh besarnya laju erosi pada setiap bentuk pola, yaitu (1) Gamal, Pisang, Nangka, Durian, Rumput 17,86 ton per hektar per tahun, (2) Coklat, Enau, Rambutan, Gamal, Serasah 10,08 ton per hektar per tahun, (3) sengon, pisang, mangga,Coklat, Kopi, Semak 4,70 ton per hektar per tahun, (4) Coklat, Pinus, Serasah 4,20 ton per hektar per tahun, (5) Enau, Coklat, Nangka, Pisang, Gamal, Serasah 3,61 ton per hektar per tahun, dan (6) Langsat, Durian, Coklat, rumput, 2,31 ton per hektar per tahun. Besarnya erosi yang terjadi pada berbagai pola usaha tani masih melebihi besarnya erosi yang diperkenankan. Untuk itu, diperlukan upaya-upaya untuk menekan laju erosi dengan melakukan praktek konservasi tanah dan bentuk penggunaan lahan yang memberikan perlindungan atau penutupan lahan yang lebih baik.
\end{abstract}




\section{PENDAHULUAN}

Kegiatan konservasi di lahan kering merupakan langkah konstruktif dapat meningkatkan fungsi lahan untuk berproduksi secara lestari, sehingga potensinya dapat dioptimalkan sebagai sumber pendapatan keluarga tani di pedesaan. Menurut Notohadiprawiro (1988), lahan kering marginal yang berstatus kritis dicirikan oleh solum tanah yang dangkal, kemiringan lereng curam, tingkat erosi telah lanjut, kandungan curam, tingkat erosi telah lanjut, kandungan bahan organic sangat rendah, serta banyak singkapan batuan di permukaan.

Kondisi demikian umumnya terdapat di wilayah desa tertinggal dan sebagian besar dikelolah oleh petani miskin yang tidak mampu melaksanakan upaya-upaya konservasi, sehingga kondisinya makin lama makin memburuk (karama dan Abdurracham, 1995).

Desa Palatta adalah salah satu desa yang ada dalam wilayah Kecamatan Tapango Kabupaten Polewali Mandar dengan panjang pantai $30 \mathrm{~km}$, yang terletak di pesisir utara dengan luas wilayah $8.500 \mathrm{Ha}$. Desa Palatta mempunyai lahan usaha tani seluasa 577,5 ha. dengan jumlah produksi 688,2 ton/tahun, Lahan-lahan usaha tani tersebut masih sangat kurang melakukan tindakan-tindakan konservasi (kondisi fisik, kondisi vegetasi). Seandainya praktek tindakan-tindakan khusus konservasi telah dilakukan jauh sebelumnya. Tentunya Iahan-lahan Usaha tani tersebut telah memiliki nilai produktivitas yang tinggi dan meningkatkan jumlah produksi yang telah dicapai.

Dua dusun di Desa Palatta memiliki variasi tingkat kemiringan lahan, dalam kondisi seperti ini dengan iklim yang sama akan menghasilkan jumlah erosi dan aliran permukaan yang berbeda. Dalam hal ini lahan yang memiliki tingkat kemiringan yang rendah, dengan penutupan tajuk yang rapat serta didukung oleh tindakan khusus konservasi tentunya akan menghasilkan jumlah erosi yang rendah.

Pelestarian produktivitas lahan usaha tani ini dapat dilakukan melalui suatu tindakan konservasi yang dapat menjamin kelestarian pengolahan Usaha tani. dalam merumuskan tindakan konservasi yang dapat menjamin kelestarian pengelolaan usaha tani dibutuhkan data kondisi sistem lahan yang ada saat ini, salah satu diantaranya adalah besarnya laju erosi yang terjadi. Dengan adanya data erosi, maka dapat dirumuskan suatu tindakan konservasi. yang berorientasi kepada konservasi tanah. Data erosi dimaksud selain dapat dijadikan dasar dalam membuat rumusan tindakan konservasi juga dapat dijadikan acuan dalam menentukan skala prioritas terhadap penanganan lahan-lahan usaha tani yang berpotensi menimbulkan erosi yang lebih besar.

Berdasarkan uraian-uraian tersebut, maka dalam penelitian ini dilakukan analisis besarnya laju erosi yang terdapat pada berbagai pola usaha tani di Desa Palatta dengan menggunakan metode USLE (Universal Soil Loss Equation). Data erosi indeks bahaya erosi dan nilai kesenjangan yang terdapat pada berbagai pola usaha tani dapat dijadikan data dasar dalam membuat suatu perencanaan Pengelolaan lahan usahatani secara menyeluruh dan lebih khusus dalam hal perencanaan pola penggunaan/pemanfaatan lahan usaha tani dan arahan dalam melakukan tindakan konservasi tanah di Desa Palatta.

Adapun tujuan dalam penelitian ini adalah :

1. Memprediksi erosi aktual dan menentukan erosi yang diperkenankan pada berbagai pola usaha tani di Desa Palatta Kecamatan Tapango Kabupaten Polewali Mandar.

2. Merumuskan tindakan konservasi tanah dan air pada setiap pola usaha tani 


\section{METODE PENELITIAN}

\section{Tempat dan Waktu Penelitian}

Penelitian ini di laksanakan di dua dusun dalam wilayah Desa Palatta yang merupakan areal usaha tani masyarakat, terletak di Kecamatan Tapango, Kabupaten Polewali Mandar, Provinsi Sulawesi Barat. Pelaksanaan penelitian pada tahun 2015.

\section{Pendekatan Penelitian}

Untuk mencapai tujuan penelitian yang telah ditetapkan, maka kegiatan yang dilaksanakan pada tahap persiapan adalah sebagai berikut :

1. Pengamatan berbagai pola Usahatani di Desa Palatta, Kecamatan Tapango, Kabupaten Polewali Mandar sebagai bakal objek penelitian.

2. Penetapan enam pola usahatani sebagai objek penelitian.

3. Pengumpulan data sekunder meliputi curah hujan; jumlah curah hujan, jumlah hari hujan, curah maksimun.

4. Pengumpulan peta-peta berupa, peta administrasi wilayah, peta geologi, peta penutupan lahan, peta kelas kemiringan lereng.

Selanjutnya pendekatan analisis untuk memprediksi besarnya erosi dan menyusun rumusan tindakan konservasi tanah dan air yang digunakan tahapan-tahapan utama sebagai berikut :

1. Analisis curah hujan untuk menentukan nilai erosivitas hujan.

2. Analisis sifat-sifat setiap jenis tanah untuk menentukan nilai erodibilitas

3. Analisis kemiringan lereng dan panjang lereng untuk menentukan nilai faktor panjang lereng dan kemiringan lereng (LS).

4. Analisis kondisi berbagai pola Usahatani dan praktek konservasi.

5. Analisis tingkat kehilangan tanah dengan pendekatan metode USLE

6. Analisis erosi diperkenankan

7. Analisis kesenjangan (GAP)

\section{Pelaksanaan Penelitian}

\section{Pengumpulan Data}

Untuk menunjang urutan perhitungan dan analisis berbagai paremeter sesuai dengan tujuan penelitian, maka diperlukan data dasar yang diperoleh dari pengamatan langsung di lapangan maupun dari data sekunder. Data dasar yang diperlukan untuk menggambarkan kondisi lahan pola usahatani untuk keperluan perhitungan atau analisis meliputi ; Lokasi, derajat kemiringan, jenis tanah, kedalaman tanah, geologi dan batuan induk.

Data klimatologi (curah hujan) diperoleh dari rekaman stasiun penakar hujan yang berada dalam /sekitar wilayah penelitian. Data curah hujan diolah sesuai dengan desain tujuan penelitian untuk memperoleh gambaran tentang curah hujan bulanan maupun tahunan.

\section{Analisis Data}

(i) Laju erosi, Model persamaan yang digunakan adalah persamaan umum kehilangan tanah atau USLE, dengan persamaan sebagai berikut :
$\mathrm{A}=$ Jumlah tanah hilang maksimum dalam ton/ha/tahun
$\mathrm{R}=$ Erosivitas hujan 
$\mathrm{K}=$ Faktor erodibilitas

LS = Indeks faktor panjang kemiringan lereng

C = Indeks faktor pengelolaan tanaman

$\mathrm{P} \quad=$ Indeks faktor teknik konservasi tanaman

\section{Dimana :}

RM = Erosivitas hujan bulanan rata-rata

(Rain) $\mathrm{m}=$ Jumlah curah hujan bulanan $(\mathrm{cm})$

(Days) $\mathrm{m}$ = Jumlah hari hujan bulanan rata-rata pada bulan tertentu

$($ Maz P)m = Curah hujan harian rata-rata maksimal pada bulan tertentu $(\mathrm{cm})$.

Perhitungan nilai erodibilitas tanah (K) oleh Wischmejer (1971) dalam Utomo, W (1994) yaitu :

$\mathrm{K}=\underline{2.71 \mathrm{M}^{1,14}\left(10^{-4}\right)(12-\mathrm{a})+2,5(\mathrm{C}-3)}$

100

Dimana :

$\mathrm{K} \quad=$ Indeks erodibilitas tanah

$\mathrm{M}=$ Parameter ukuran butir yang diperoleh dari

a $\quad=$ Presentase bahan organic $(\% \mathrm{C} \times 1,724)$

b $\quad=$ Kode struktur tanah

c $\quad=$ Kode permeabilitas tanah

Perhitungan nilai faktor panjang dan kemiringan lereng (LS) dengan persamaan/rumusan, yaitu :

LS $=[\text { panjang lereng/22,1 }]^{\mathrm{m}^{*}}\left[0,00641 \mathrm{~S}^{2}+0,0456 \mathrm{~S}+0,065\right]$

Dimana :

$\mathrm{S}=$ kemiringan dalam $\%$

$m=0,5$ jika kemiringan lereng sama dengan $5 \%$ atau lebih 0,4 jika kemiringan lereng 3,5 - 4,5\%

0,3 jika kemiringan lereng $1-3 \%$

0,2 jika kemiringan lereng lebih kecil dari $1 \%$

Nilai faktor $\mathrm{C}$ dapat diketahui melalui penelusuran hasil penelitian dan pengecekan lokasi yang meliputi kondisi penutupan tajuk, penutupan permukaan lahan usaha tani secara keseluruhan, apakah berupa semak dan serasah.

Untuk menentukan besarnya nilai faktor pengelolaan tanaman (nilai C) pada setiap pola usaha tani. Rujukan di dalam penentuan nilai $\mathrm{C}$ adalah seperti disajikan pada tabel berikut :

Tabel 1.

Nilai factor $\mathrm{C}$ pada berbagai macam penggunaan lahan.

\begin{tabular}{|c|c|c|}
\hline No & Macam Penggunaan & Nilai Faktor \\
\hline 1. & Tanah terbuka / tanpa tanaman .......... & 0,1 \\
\hline 2. & Sawah $\ldots \ldots \ldots \ldots \ldots \ldots \ldots \ldots$ & 0,01 \\
\hline 3. & Tegalan tidak dispesifikasi & 0,07 \\
\hline 4. & Ubi kayu . & 0,8 \\
\hline 5. & Jagung ........... & 0,7 \\
\hline 6. & Kedelai ............ & 0,399 \\
\hline 7. & Kentang ............ & 0,4 \\
\hline 8. & Kacang Tanah... & 0,2 \\
\hline 9. & Padi ............... & 0,561 \\
\hline 10. & 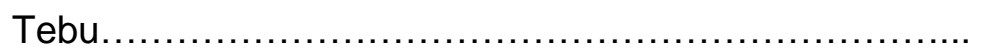 & 0,2 \\
\hline 11. & Pisang & 0,6 \\
\hline 12. & 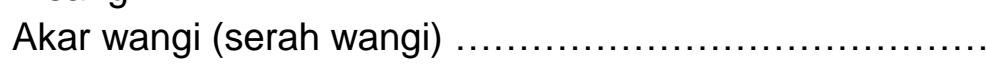 & 0,4 \\
\hline
\end{tabular}


13. Rumput bede (tahun pertama) ............................

14. Rumput bede (tahun kedua) .................................

15. Kopi dengan penutup tanah buruk ..........................

16. Talas ......................................................

17. Kebun Campuran : - Kerapatan Tinggi ......................

- Kerapatan rendah ........................

18. Perladangan .....................................................

19. Hutan Alam : - Seranggah banyak ............................

- Seranggah Kurang ........................... 0,005

20. Hutan Produksi : - terbang habis ...........................

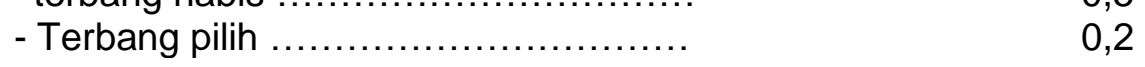

21. Semak Belukar/padang rumput ..............................

22. Ubi kayu + kedelai ....................................

23. Ubi kayu + kacang tanah..................................

24. Padi - Sorghum .............................................

25. Padi - Kedelai ...............................................

26. Kacang tanah + Gude .................................

27. Kacang tanah + kacang tunggak ........................

28. Kacang tanah + Mulsa jerami 4 ton/ha .....................

29. Padi + Mulsa jagung 4 ton/ha ............................

30. Kacang tanah + Mulsa jagung 3 ton/ha ..................

31. Kacang tanah + Mulsa crotalaria 3 ton/ha ................ 0,136

32. Kacang tanah + Mulsa kacang tunggak ...................

33. Kacang tanah + Mulsa jerami 2 ton/ha .....................

34. Padi + Mulsa Crotalaria 3 ton/ha ..........................

35. Pola tanam tumpang gulir $\left.{ }^{* *}\right)+$ Mulsa jerami ................ 0,079

36. Pola tanam berurutan $\left.{ }^{* \star *}\right)+$ Mulsa sisa tanaman ............

37. Alang-alang murni subur .................................. 0,001

Sumber : konservasi tanah dan air. C.Arsyad, 1989

Tabel.2

Klas tingkat bahaya erosi (Departemen Kehutanan, 1986).

\begin{tabular}{|c|c|c|c|c|c|c|}
\hline \multicolumn{7}{|c|}{ Klas Erosi } \\
\hline & Erosi & I & II & III & IV & V \\
\hline \multicolumn{7}{|c|}{ Erosi ton/ha/tahun } \\
\hline \multicolumn{2}{|r|}{$\begin{array}{l}\text { Solusi } \\
\text { Tanah cm }\end{array}$} & $<15$ & $15-60$ & $60-180$ & $180-480$ & $>480$ \\
\hline A & Dalam & $\begin{array}{c}\mathrm{SR} \\
0\end{array}$ & $\begin{array}{l}R \\
1\end{array}$ & S & B & SB \\
\hline \multirow{2}{*}{ B } & Sedana & $B$ & $\mathrm{~s}$ & $\mathrm{SB}$ & $\mathrm{SB}$ & $\mathrm{SB}$ \\
\hline & $30-60$ & 0 & 1 & II & III & IV \\
\hline \multirow{2}{*}{ C } & Dangkal & S & SB & SB & SB & SB \\
\hline & $30-60$ & 0 & $\mathrm{I}$ & II & III & IV \\
\hline \multirow{2}{*}{ D } & Sangat Dangkal & $B$ & SB & SB & SB & SB \\
\hline & $>30$ & 0 & I & II & III & IV \\
\hline
\end{tabular}

$\begin{array}{ll}\text { Keterangan : } & \\ \text { O-SR } & =\text { Sangat Ringan } \\ \mathrm{I}-\mathrm{R} & =\text { Ringan } \\ \mathrm{II}-\mathrm{B} & =\text { Sedang } \\ \mathrm{III}-\mathrm{B} & =\text { Berat } \\ \mathrm{IV}-\mathrm{SB} & =\text { Sangat Berat }\end{array}$


(ii) tingkat bahaya erosi adalah jumlah tanah hilang maksimumnya yang masih diperbolehkan pada setiap unit lahan, dengan memperhitungkan kedalaman tanah efektif setiap unit lahan. Klasifikasi tingkat bahaya erosi ditunjukkan pada tabel 2.

(iii) kehilangan tanah yang dapat dibiarkan atau Tolerable Soil Loss (TSL) adalah batas maksimum erosi tanah yang diperkenankan dimana produktifitas tanah masih dapat dipertahankan secara ekonomis dan lestari (Wischmeier dan Smith, 1978). Hammer(1978). Hammer (1981) mengenalkan konsep kehilangan tanah yang dapat dibiarkan (TSL) dengan mempertimbangkan umur guna tanah yaitu waktu yang diperlukan untuk habis tererosinya suatu kedalam tanah.

Pada konsep ini, laju TSL ditentukan menurut fungsi hubungan :

$T S L=\frac{K E-F K}{U G T}$

Dimana TSL adalah laju erosi yang masih dapat dibiarkan (mm/tahun atau ton/ha/tahun), KE adalah ke dalam efektif $(\mathrm{mm})$, FK adalah faktor kedalaman tanah dapat dilihat pada Tabel 10. dan UGT adalah umur guna tanah (untuk kepentingan pelestarian digunakan 400 tahun).

Informasi Indeks Bahaya Erosi klasifikasinya sangat diperlukan dalam menentukan daerah prioritas yang harus direhabilitasi lahannya.

Indeks Bahaya Erosi ditentukan dari perhitungan nisbah antara laju erosi tanah potensial (A) yaitu fungsi dari topografi, erodibilitas tanah dan erosivitas hujan dengan laju erosi yang masih dapat ditoleransi (TSL), atau secara persamaan matematis dapat ditulis sebagai berikut (Hammer, 1881).

Indeks bahaya erosi $\frac{\text { A.(ton ha tahun) }}{\text { TSL (ton ha tahun) }}$

(6)

Klasifikasi indeks bahaya erosi menurut Hammer. (1981) adalah sebagaimana tabel 1 ditentukan dalam penyeleggara pengelolaan DAS, karena keberhasilan maupun kegagalan hasil kegiatan pengelolaan DAS dapat dimonitor dan dievaluasi melalui kriteria dan indikator yang telah ditetapkan.

Kriteria penilaian erosi menurut Departemen Kehutanan (2000) dikenal dengan indkes erosi(IE), yaitu perbandingan antara erosi aktual dengan TSL. Jika IE $>1$, maka kriterianya baik, sebaliknya $\mathrm{IE}>1$, adalah jelek.

\section{Erosi yang diperkenankan}

Penentuan erosi yang diperkenankan atau disebut nilai $\mathrm{T}$, didasarkan pada sifat tanah dan subsratumnya seperti yang tercanum didalam tabel berikut ini:

Tabel.3

Pedoman Penetapan Nilai T untuk Tanah-tanah di Indonesia

\begin{tabular}{|c|c|}
\hline Sifat tanah dan Substatum & $\begin{array}{l}\text { Nilai T (mm per } \\
\text { tahun) }\end{array}$ \\
\hline 1. Tanah sangat dangkal diatas batuan & 0,0 \\
\hline 2. Tanah sangat dangkal diatas bahan melapuk (tidak diatas & 0,4 \\
\hline terkonsolidasi). & 0,8 \\
\hline 3. Tanah dangkal diatas bahan telah melapuk & 1,2 \\
\hline 4. Tanah dalam kedalaman sedang telah melapuk. & \\
\hline $\begin{array}{l}\text { 5. Tanah yang dalam dengan lapisan bawah yang kedap air diatas substrata } \\
\text { telah yang telah melapuk................... }\end{array}$ & 1,4 \\
\hline $\begin{array}{l}\text { 6. Tanah yang dalam dengan lapisan bawah berpermeabilitas lambat, diatas } \\
\text { substrata telah melapuk................. }\end{array}$ & 1,6 \\
\hline $\begin{array}{l}\text { 7. Tanah yang dalam dengan lapisan bawahnya berpermealibilitas sedang, } \\
\text { diatas sustrata telah melapuk ............... }\end{array}$ & 2,0 \\
\hline $\begin{array}{l}\text { 8. Tanah yang dalam dengan lapisan bawah yang permeable diatas substrata } \\
\text { telah melapuk .................... }\end{array}$ & 2,5 \\
\hline
\end{tabular}

*) $\mathrm{mmx}$ berat volume $\times 10=$ ton/ha/tahun

*) berat volume tanah berkisar antara 0,8 sampai $1.6 \mathrm{gr} / \mathrm{cc}$ akan tetapi pada umumnya tanah berkadar liat tinggi mempunyai berat antara 0,1 samapai 1,2 gricc 


\section{HASIL DAN PEMBAHASAN}

\section{A. Prediksi Erosi}

\section{Unit Lahan Usaha Tani}

Unit Lahan Usaha Tani merupakan suatu kesatuan lahan yang arealnya relatif seragam atas sejumlah faktor penentu erosi. Unit lahan diperoleh berdasarkan hasil penetapan orientasi dan berbagai pola usaha tani yang ada di Desa Palatta. Hasil Orientasi tersebut ditetapkan sejumlah 6 (enam) pola usaha tani yang masing-masing mempunyai karakteristik yang berbeda seperti komposisi jenis penyusun dan derajat kemiringan.

Komposisi jenis penyusun erat hubungannya dengan kerapatan tiap jenis dari keenam pola usaha tani, yang tercatat sebagai berikut :

- Pola A enau, coklat, lansat, nangka, pisang, serasah; dengan jarak tanam enau $=4 \times 5 \mathrm{~m}$, coklat $=2,5 \times 3 \mathrm{~m}$, langsat - nangka $=3,5 \times 4 \mathrm{~m}$, pisang-pisang $=4 \times 4 \mathrm{~m}$; dengna kerapatan 64 tanaman + tanaman pisang 3 - rumpun/0,9 $\mathrm{Ha}$.

- Pola B coklat, pinus, serasah; dengan jarak tanam coklat $=2,5 \times 3 \mathrm{~m}$, pinus $=3 \times 5 \mathrm{~m}$; dengan kerapatan 67 pohon/0,6 Ha.

- Pola C gamal, pisang, nangka, durian, rumput; dengan jarak tanam gamal - gamal $=3 \times 3 \mathrm{~m}$, pisang-pisang $=10 \times 10 \mathrm{~m}$, durian-durian $=5 \times 6 \mathrm{~m}$, nangka-durian $=5 \mathrm{~m}$; dengan kerapatan 65 pohon + tanaman pisang 4 rumpun/ $1,1 \mathrm{Ha}$.

- Pola D coklat, enau, rambutan, gamal, serasah; dengan jarak tanam coklat $=2,5 \times 3 \mathrm{~m}$, enau = $4 \times 5 \mathrm{~m}$, gamal - rambutan $=4 \mathrm{~m}$; dengan kerapatan 57 pohon $/ 1,2 \mathrm{Ha}$

- Pola E langsat, coklat, durian, rumput; dengan jarak langsat $=4 \times 5 \mathrm{~m}$, coklat $=2,5 \times 3 \mathrm{~m}$, durian $=5 \times 6 \mathrm{~m}$, dengan kerapatan 63 pohon $/ 1,4 \mathrm{Ha}$.

- Pola F sengon, pisang, mangga, coklat, kopi, semak; dengan jarak tanam sengon $=3 \times 3 \mathrm{~cm}$, pisang $=4 \times 5 \mathrm{~m}$, coklat $=4 \times 4 \mathrm{~m}$, kopi-mangga $=4 \mathrm{~m}$; dengan kerapatan 69 tanaman $/ 1,3$ Ha.

Keenam unit lahan pola usaha tani ini dijadikan satuan lahan dalam analisis selanjutnya. Karakteristik komponen pembentuk setiap unit lahan usaha tani ditunjukan pada table 21.

\section{Laju Erosi}

Erosi adalah peristiwa pindahnya atau tersangkutnya tanah atau bagian-bagian tanah dari suatu tempat ke tempat lain oleh media alam. Laju erosi dalam penelitian ini dihitung dengan menggunakan USLE (Universal Soil LoSs Equation). Berdasarkan nilai-nilai faktor penyebab erosi sesuai persamaan USLE dalam menduga besarnya laju erosi setiap unit lahan ditunjukkan pada tabel 21 besarnya erosi yang terjadi pada 6 (enam) lahan pola usaha tanidapat dihitung dengan menggunakan nilai dari faktor-faktor, erositas $(R)$ erodibilitas $(K)$, panjang dan kemiringan lereng (LS), faktor tanaman (C), dan konservasi tanah (P). berdasarkan nilai faktor-faktor (RKLSCP), maka besarnya erosi yang terjadi pada 6 (enam) pola usaha tani adalah 17,86 ton/ha/tahun. Berdasarkan keenam pola usaha tani, maka besarnya laju erosi pada setiap bentuk pola yaitu Coklat, Enau, Rambutan, Gamal, Serasah sebesar 10,08 ton/ha/tahun; Sengon, Pisang, Mangga, Coklat, Kopi, Semak sebesar 4,70 ton/ha/tahun; Coklat, Pinus, Serasah sebesar 4,20 ton/ha/tahun; Enau, Coklat, Langsat, Nangka, Pisang, Gamal, Serasah sebesar 3,61 ton/ha/tahun; dan langsat, Durian, Coklat, Rumput sebesar 2,31 ton/ha/tahun. 
Penetapan batas tertinggi erosi yang masih dapat dibiarkan atau ditoleransikan (Tolerable Soil Loss) keenam unit lahan pola usahatani Desa Palatta ditunjukkan dalam tabel 22. Sedang nial erosi yang diperkenankan untuk keenam pola usaha tani tersebut yaitu antara 0,8 sampai 2,0 ton/ha/tahun. Penetapan batas tertinggi laju erosi yang masih dapat dibiarkan adalah penting, karena tidak mungkin menekan laju erosi menjadi nol dari tanah yang diusahakan untuk pertanian terutama tanah yang belerang.

Dengan adanya batas tertinggi laju erosi yang masih dapat dibiarkan dalam suatu unit lahan, maka kedalaman tanah akan terpelihara yang cukup bagi pertumbuhan tanaman untuk mencapai produktivitas yang tinggi secara lestari.

Evaluasi akhir dari erosi potensial dinyatakan dalam indeks bahaya (ancaman) erosi yang dihitung dengan persamaan :

Indeks Bahaya Erosi $=\frac{\text { Erosi Potensial (ton/ha/thn) }}{\text { TSL (ton ha tahun) }}$

Dimana : TSL adalah besarnya erosi yang masih dapat dibiarkan.

Tabel 4.

Besarnya erosi potensial dan aktual pada 6 (enam) unit lahan pola usahatani di Desa Palatta

\begin{tabular}{|c|c|c|c|c|c|c|c|c|}
\hline \multirow[b]{2}{*}{$\begin{array}{l}\text { Pola } \\
\text { tanam }\end{array}$} & \multirow[b]{2}{*}{ Kombinasi Tanaman } & \multirow[b]{2}{*}{$\mathrm{R}$} & \multirow[b]{2}{*}{$\mathrm{K}$} & \multirow[b]{2}{*}{ LS } & \multirow[b]{2}{*}{ C } & \multirow[b]{2}{*}{$\mathrm{P}$} & \multicolumn{2}{|c|}{ Erosi } \\
\hline & & & & & & & $\begin{array}{c}\text { Potensial } \\
\left(R^{*} K^{*} L S\right) \\
\text { Ton/ha/tahun }\end{array}$ & $\begin{array}{c}\text { Aktual } \\
\left(R^{\star} K^{\star} L S^{*} C P\right) \\
\text { Ton/ha/tahun }\end{array}$ \\
\hline 1 & $\begin{array}{l}\text { Enau coklat, langsat, } \\
\text { nangka, pisang, gamal, } \\
\text { serasah }\end{array}$ & 2102 & 0,43 & 0,02 & 0,2 & 1 & 18,08 & 3,61 \\
\hline 2 & Coklat, pinus, serasah & 2102 & 0,25 & 0,04 & 0,2 & 1 & 21,02 & 4,20 \\
\hline 3 & $\begin{array}{l}\text { Gamal, pisang, nangka, } \\
\text { durian, rumput }\end{array}$ & 2102 & 0,34 & 0,05 & 0,5 & 1 & 35,73 & 17,86 \\
\hline 4 & $\begin{array}{l}\text { Coklat, enau, rambutan, } \\
\text { gamal, serasah }\end{array}$ & 2102 & 0,48 & 0,05 & 0,2 & 1 & 50,45 & 10,08 \\
\hline 5 & $\begin{array}{l}\text { Langsat, durian, coklat, } \\
\text { kemiri, rumput }\end{array}$ & 2102 & 0,11 & 0,02 & 0,5 & 1 & 4,624 & 2,31 \\
\hline 6 & $\begin{array}{l}\text { Sengon, pisang, mangga, } \\
\text { coklat, kopi, semak }\end{array}$ & 2102 & 0,04 & 0,04 & 0,2 & 1 & 23,54 & 4,70 \\
\hline
\end{tabular}

Tabel 5.

Nilai indeks bahaya erosi (IBE) keenam lahan pola usaha tani di Desa Palatta

\begin{tabular}{|c|c|c|c|c|c|}
\hline \multirow[t]{2}{*}{$\begin{array}{l}\text { Pola } \\
\text { tanam }\end{array}$} & \multirow[t]{2}{*}{ Kombinasi Tanaman } & \multirow[t]{2}{*}{$\begin{array}{l}\text { Erosi Potensial } \\
\text { (ton/ha/tahun) }\end{array}$} & \multirow{2}{*}{$\begin{array}{c}\text { TSL } \\
\text { (ton/ha/ } \\
\text { tahun) }\end{array}$} & \multicolumn{2}{|c|}{$\begin{array}{l}\text { Indeks Bahaya Erosi } \\
\text { Erosi Potensial } \\
\text { TSL }\end{array}$} \\
\hline & & & & Nilai & Harkat \\
\hline A & $\begin{array}{l}\text { Enau coklat, langsat, } \\
\text { nangka, pisang, gamal, } \\
\text { serasah }\end{array}$ & 18,08 & 2,0 & 9,04 & Rendah \\
\hline B & Coklat, pinus, serasah & 21,02 & 1,6 & 13,13 & Tinggi \\
\hline C & $\begin{array}{l}\text { Gamal, pisang, nangka, } \\
\text { durian, rumput }\end{array}$ & 35,73 & 0,8 & 44,66 & $\begin{array}{r}\text { Sangat } \\
\text { Tinggi }\end{array}$ \\
\hline D & $\begin{array}{l}\text { Coklat, enau, rambutan, } \\
\text { gamal, serasah }\end{array}$ & 50,45 & 0,8 & 63,06 & $\begin{array}{l}\text { Sangat } \\
\text { Tinggi }\end{array}$ \\
\hline$E$ & $\begin{array}{l}\text { Langsat, durian, coklat, } \\
\text { kemiri, rumput }\end{array}$ & 4,62 & 2,0 & 2,31 & Rendah \\
\hline
\end{tabular}




$\begin{array}{llllll}\text { F } & \begin{array}{l}\text { Sengon, pisang, mangga, } \\ \text { coklat, kopi, semak }\end{array} & 23,54 & 1,6 & 14,71 & \text { Tinggi }\end{array}$

\section{B. Nilai Kesenjangan (GAP)}

Berdasarkan hasil perhitungan erosi aktual dan erosi diperkenankan pada 6 (enam) pola usaha tani di Desa Palatta, terdapat nilai kesenjangan dapat di peroleh apabila nilai erosi actual lebih besar dari erosi diperkenankan, seperti ditunjukkan pada Tabel 6.

\section{Rumusan Tindakan Konservasi}

Berdasarkan hasil analisis kesenjangan (GAP) pada (enam) pola usaha tani di Desa Palatta, semua pola usaha tani perlu mendapat berbagai tindakan konservasi (vegetative, mekanik), agar erosi yang terjadi pada setiap pola usaha tani lebih kecil dari erosi yang diperkenankan, rumusan tindakan konservasi keenam pola usaha tani ditunjukan pada Tabel 7.

Tabel 6.

Nilai kesenjangan pada berbagai pola usaha tani di Desa Palatta

\begin{tabular}{clccc}
\hline $\begin{array}{c}\text { Pola } \\
\text { tana } \\
\text { man }\end{array}$ & Kombinasi Tanaman & $\begin{array}{c}\text { Erosi aktual (A) } \\
\text { (ton/ha/thn) }\end{array}$ & $\begin{array}{c}\text { Erosi } \\
\text { Diperkenankan (T) } \\
\text { (ton/ha/thn) }\end{array}$ & $\begin{array}{c}\text { Kesenjangan } \\
\text { (GAP) } \\
\text { (ton/ha/thn) }\end{array}$ \\
\hline A & $\begin{array}{l}\text { Enau coklat, langsat, nangka, } \\
\text { pisang, gamal, serasah }\end{array}$ & 3,61 & 2,0 & $-1,61$ \\
\hline B & Coklat, pinus, serasah & 4,20 & 1,6 & $-2,6$ \\
\hline C & $\begin{array}{l}\text { Gamal, pisang, nangka, } \\
\text { durian, rumput }\end{array}$ & 17,86 & 0,8 & $-17,06$ \\
\hline D & $\begin{array}{l}\text { Coklat, enau, rambutan, } \\
\text { gamal, serasah }\end{array}$ & 10,08 & 0,8 & -9.28 \\
\hline E & $\begin{array}{l}\text { Langsat, durian, coklat, kemiri, } \\
\text { rumput }\end{array}$ & 2,31 & 2,0 & $-0,31$ \\
\hline F & $\begin{array}{l}\text { Sengon, pisang, mangga, } \\
\text { coklat, kopi, semak }\end{array}$ & 4,70 & 1,6 & $-3,1$ \\
\hline
\end{tabular}

Tabel 7.

Rumusan tindakan konservasi pada berbagai pola usaha tani di Desa Palatta

\begin{tabular}{|c|c|c|c|c|}
\hline \multirow{2}{*}{$\begin{array}{l}\text { Pola } \\
\text { tanam }\end{array}$} & \multirow{2}{*}{ Kombinasi Tanaman } & \multicolumn{2}{|c|}{ Tindakan } & \multirow{2}{*}{$\begin{array}{l}\text { Tindakan } \\
\text { Vegetasi }\end{array}$} \\
\hline & & Fisik & $\begin{array}{l}\text { Nilai } \\
\text { faktor }\end{array}$ & \\
\hline A & $\begin{array}{l}\text { Enau coklat, langsat, } \\
\text { nangka, pisang, gamal, } \\
\text { serasah }\end{array}$ & $\begin{array}{l}\text { - Pembuatan teras } \\
\text { tradisional }\end{array}$ & 0,35 & $\begin{array}{l}\text { - Penambahan tanaman } \\
\text { pisang } \\
\text {-Penambahan tanaman } \\
\text { gamal }\end{array}$ \\
\hline B & Coklat, pinus, serasah & - Kontur cropping & 0,90 & $\begin{array}{l}\text { - Penambahan tanaman } \\
\text { coklat }\end{array}$ \\
\hline C & $\begin{array}{l}\text { Gamal, pisang, nangka, } \\
\text { durian, rumput }\end{array}$ & $\begin{array}{l}\text { - Strip rumput } \\
\text { permanen } \\
\text { - Pemb. Teras } \\
\text { bangku } \\
\end{array}$ & $\begin{array}{l}0,40 \\
0,15\end{array}$ & $\begin{array}{l}\text { - Penanaman Lantoro } \\
\text { - Penambahan tanaman } \\
\text { pisang dan gamal }\end{array}$ \\
\hline D & $\begin{array}{l}\text { Coklat, enau, rambutan, } \\
\text { gamal, serasah }\end{array}$ & $\begin{array}{l}\text { - Pembuatan teras } \\
\text { tradisional } \\
\text {-Strip crotolaria }\end{array}$ & $\begin{array}{c}0,35 \\
0,5\end{array}$ & $\begin{array}{l}\text { - Penambahan tanaman } \\
\text { rambutan } \\
\text { - Penambahan tanaman } \\
\text { gamal dan coklat }\end{array}$ \\
\hline$E$ & $\begin{array}{l}\text { Langsat, durian, coklat, } \\
\text { kemiri, rumput }\end{array}$ & $\begin{array}{l}\text { - Strip rumput } \\
\text { permanen }\end{array}$ & 0,04 & $\begin{array}{l}\text { - Penambahan tanaman } \\
\text { durian } \\
\text { - Penanaman tanaman }\end{array}$ \\
\hline
\end{tabular}




\section{Kesimpulan}

\section{KESIMPULAN DAN SARAN}

1. Besarnya laju erosi yang terjadi pada 6 (enam) pola usaha tani di Desa Palatta sebesar 42,76 ton ha/tahun sedang besarnya nilai erosi yang ditoleransikan atau dibiarkan (Tolerable Soil Loss) pada masing-masing pola usaha tani yaitu antara ... sampai ...to/ha/tahun.

2. Berdasarkan faktor tanaman dan komposisi jenis penyusun berupa Gamal, Pisang, Nangka, Durian, Rumput merupakan penyumbang erosi terbesar di lahan-lahan usahatani Desa Palatta yaitu 17,86 ton/ha/tahun; yang kemudian berturut-turut Coklat, Enau, Rambutan, Gamal, Serasah sebesar 10,08 ton/ha/tahun; Sengon, Pisang, Mangga, Coklat, Kopi, Semak sebesar 4,70 ton/ha/tahun; Coklat, Pinus, Serasah sebesar 4,20 ton/ha/tahun; Enau, Coklat, Langsat, Nangka, Pisang, Gamal, serasah sebesar 3,61 ton/ha/tahun; dan Langsat, Durian, Coklat, Rumput sebesar 2,31 ton/ha/tahun. Langsat, Durian, Coklat, Rumput merupakan penyumbang erosi terkecil, karena disamping memiliki jarak tanaman rapat juga memiliki derajat kemiringan yang paling rendah.

3. Berdasarkan hasil analisis kesenjangan (GAP) pada 6 (enam) pola usahatani di Desa Palatta, pada dasarnya semua pola usahatani perlu mendapat berbagai tindakan khusus konservasi (kondisi fisik, kondisi vegetasi). Rumusan tindakan konservasi masing-masing pola usahatani untuk tindakan fisik yaitu pola enau, coklat, langsat, nangka, pisang, gamal, serasah tindakan fisiknya (Pembuatan teras tradisional, Strip rumput permanen); pola coklat, pinus, serasah; tindakan fisiknya (Kontur Cropping); pola gamal, pisang, nangka, durian, rumput, tindakan fisiknya (Strip rumput permanen, pembuatan teras bangku); pola coklat, enau, rambutan, gamal, serasah, tindakan fisiknya (pembuatan teras tradisional, strip, clotolaria); pola langsat, durian, coklat, rumput, tindakan fisiknya (strip rumput permanen); pola sengon, pisang, mangga, coklat, kopi, semak, tindakan fisiknya (kontur cropping).

4. Semua pola usaha tani perlu mendapat tindakan vegetasi yang disetujui oleh para petani (penambahan jenis tanaman yang sama, penanaman jenis lain).

\section{Saran}

1. Besarnya erosi yang terjadi pada 6 (enam) pola usaha tani di Desa Palatta, semua pola usaha tani menghasilkan besarnya erosi melebihi erosi diperkenankan, oleh karena itu kegiatan pemanfaatan lahan usaha tani yang ada di Desa Palatta sudah harus diikuti dengan praktek-praktek konservasi tanah yang lebih baik.

2. Pola penggunaan lahan usahatani yang ada di Desa Palatta disarankan agar lebih berorientasi kepada bentuk penggunaan lahan pertanian hutan (agroforestry) yang dapat membentuk struktur tajuk yang bertingkat dan rapat serta penutupan lahan (land cover) yang baik, diantaranya pemanfaatan tumbuhan bawah. 


\section{DAFTAR PUSTAKA}

Arsyad, C., 200. Konservasi Tanah dan Airi. IPB Press. Bogor.

Asdak. 2002. Hidrologi dan Pengelolaan Daerah Aliran Sungai. Gadjah Mada Universitas Pres. Yogyakarta.

Basyar, Ahmad. 2006. Evaluasi Perubahan Perilaku Evolusi Daerah Aliran Sungai Citarum Hulu

Dengan Pemodelan Spasis

http://www.ftsl.itb.ac.id/wpcontect/uploads/2007/04/art.74125.153.132/search?q=chache:sm.

Beasley, R.P. 1972. Erosion and Sediment Pollution Control. The lowa State University Press, Ames lowa.

Buckman, H.O dan N.C. Brady, 1982: Ilmu Tanah. Terjemahan Soegiman. Bhratara, Jakarta.

Clark II, Havekamp \& Chapman, 1985 dalam Jumartina Sihite. 2001. Evaluasi Dampak Erosi Tanah.

http://72.14.235.132/Search?q=chache.thjo.360bhmi:www.woridagroforestry.org/seaf.publicati ons/file.

Departemen Kehutanan. 1986 Pedoman Penyusunan Rencana teknik Lapangan Rehabilitasi lahan dan konservasi Tanah Daerah Aliran Sungai. Direktorat Jendral Reboisasi dan Rehabilitasi Lahan, Jakarta.

Hammer, W.I. 1981. Final Soil Conservation Consultant Report. Tech. Note No. 26. Centre For Soil Research, Bogor.

Hardjowigeno, 1987. IImu Tanah. CV akademika Pressindo. Jakarta.

Hardjowigeno, S. 1987. IImu Tanah. PT. Medyatama Sarana Perkasa, Jakarta.

Jansson, M.B. 1982. Land Erosion by Water in Different Climates. Departement of Physic. Geograph.

Uppsala Univ. UNG/Rapport No. 57. Sweden.

Karama, ..........1988. Potensi Dampak Pengembangan Pola Tanam.

http://pse.litbang.deptan.go.id/ind/pdf.files/FAE22-2d.pdf.

Karama dan abdulrraxman 1995. Usaha Konservasi Tanah dan Air Sebagai Alternatif Peningkatan

Pendapatan Petani di Lahan Kering (Kasus Konservasi Tanah dan Air di Desa Rejosari, Kecamatan Semin, Kabupaten Gunungkidul, Propinsi DIY).

http://ntb.litbang.deptan.go.id/2005/sp/usahakonservasi.doc

Kasryno. 2003. Potensi Dampak Pengembangan Pola Tanam.

http://pse.litbang.deptan.go.id.ind/pdf.files/FAE22-2d.pdf.

Kooiman, A.1987. The Factor C.Internasional Institute for Surveys and Earth Sciences (I.T.C) Land

Resources and Rural Development, Departement of Rural and Land Ecology Survey,

Enschede, The Nethelands.

Morgan, R.P.C. 1979. Soil Erosian and Conservation Longman, London.

Nasiah. 2000. Evaluasi Kemampuan Lahan dan Tingkat Bahaya Erosi Untuk Prioritas Konservasi

Lahan di Daerah Aliran Sungai Takapala Dati II Gowa Propinsi Sulawesi Selatan. Tesis Progman pasca sarjana. UGM Yogyakarta.

Notohadiprawiro. 1988. Usaha Konservasi Tanah dan Air Sebagai Alternatif Peningkatan

Pendapatan Petani di Lahan Kering (Kasus Konservasi Lahan dan Air di Desa Rejosari, Kecamatan

Semin, Kabupaten Gunung kidul, Propinsi DIY).

http://ntb.litbang.deptan.go.id/20451splusahakonservasi.doc 
Rahim, SE. 2000. Pengendalian Erosi Tanah dalam Rangka Pelestarian Lingkungan Hidup. Bumi Aksara. Jakarta

Seta, A.K. 1991. Konservasi Sumberdaya Tanah dan Air. Kalam Mulia. jakarta.

Setjana. 1983. potensi dampak pengembangan pola tanam.

http://samruni.blongspot.com/2008/01/usahatani-konservasi-untuk-pelestarian.html

Sjarullah. 1987. Pengertian dan bentuk-bentuk erosi

http://samruni.blongspot.com/2009/01/pengertian-dan-bentuk-bentuk-erosi.html.

Sinukaban. 1995. Dalam Marwah 2001. Usaha Tani Konservasi untuk Pelestarian Sumber Daya Alam. http://ucupneptune.blongspot.com/2008/01/usahatani-konservasi-untuk-pelestarian.html. Sinukaban. 2003. Dalam Suhardi 2003. Usaha Tani Konservasi untuk pelestarian sumber daya alam. http://ucupneptune.blongspot.com/2008/01/usahatani-konservasi-untuk-pelestarian,html

Soewandito, ..... 2002. Usaha Tani konservasi untuk pelestarian sumber daya alam

http://ucupneptune.blongspot.com/2008/01/usahatani-konservasi-untuk-pelestarian.html

Timmer. 1992. Potensi dampak pengembangan pola tanam.

http://pse.litbang.deptan.go.id/ind/pdf.files/FAE22-2d.pdf.

Tropical Soil Manual, BookerAgriculture Internasional Limited, 1984.

Utomo W.H., 1994. Erosi dan Konservasi Tanah. IKIP MALANG.

Wischme, W.H and Smith, D.D. 1978. Predicting Rainfall Erosion Losses A Gide to Conservation Planning; USDA Agric. Handbook. No.537. 